\title{
Pengaruh Kemampuan Matematika Terhadap Kemampuan Computational Thinking Pada Anak Usia Sekolah Dasar
}

\author{
1Heri Kuswanto, ${ }^{2}$ Nani Rodiyanti, ${ }^{3}$ Yosi Nur Kholisho, ${ }^{4}$ Baiq Desi Dwi Arianti \\ 1heriku@hamzanwadi.ac.id, 2nanirodiyanti@gmail.com, ${ }^{3}$ yosink.peninfo@gmail.com, \\ ${ }^{4}$ ariantibaiq@hamzanwadi.ac.id \\ 1,2,3,4 Universitas Hamzanwadi, Lombok, Indonesia 3
}

\begin{abstract}
Computational thinking ability need to be trained from an early age through the mathematics ability approach at the primary schools level. This study aims to analyze the effect of the analysis of mathematic ability to computational thinking abilities in primary schools age in sdn 2 sekarteja with 2 measurement variables including: computational thinking ability and math ability. This type of research is quantitative using descriptive methods. The population of this study was class V SDN 2 Sekarteja with a total of 30 students and the entire population becomes the sample, the type of research sample is saturated sample. Data collection techniques in this study used tests and documentation. The technique used to analyze the data was descriptive statistics. The results of this study indicated that, with $n=30$ and a significant level of $5 \%, r$ table $=0.361$, while the result rcount $=0.304$. The results obtained were rcount $\leq$ rtabel, then Ha was rejected and Ho was accepted and the direction of the correlation was negative. It can be concluded that there was no significant relationship between the computational thinking abilities of elementary school age children in terms of mathematics abilities at SDN 2 Sekarteja.
\end{abstract}

\section{Kata Kunci: mathematics ability, Computational Thinking ability, computational thinking}

\begin{abstract}
Abstrak
Kemampuan berpikir komputasional perlu dilatih sejak usia dini melalui pendekatan kemampuan matematika pada tingkat sekolah dasar. Tujuan dalam penelitian ini untuk menganalisis kemampuan matematika terhadap kemampuan computational thinking pada anak usia sekolah dasar. Penelitian ini merupakan penelitian deskriptif kuantitatif, dengan populasi sebesar 30 orang siswa kelas V SDN 2 Sekartea dan dengan menggunakan sampel jenuh. Teknik pengumpulan data menggunakan tes dan dokumentasi dengan analisis data statistik deskriptif. Hasil penelitian menunjukkan bahwa, tidak terdapat hubungan yang signifikan antara pengaruh kemampuan computational thinking dengan kemampuan matematika, dengan $n=30$ dan taraf signifikan $5 \%$ diperoleh rtabel $=0,361$, sedangkan hasil rhitung $=$ 0,304 . Hasil yang diperoleh adalah rhitung $\leq$ rtabel maka Ha ditolak dan Ho diterima serta arah korelasinya negatif. Sehingga dapat disimpulkan bahwa tidak terdapat hubungan yang signifikan antara kemampuan computational thinking anak usia sekolah dasar ditinjau dari kemampuan matematika di SDN 2 Sekarteja.
\end{abstract}

Kata Kunci: kemampuan matematika, kemampuan Computational Thinking, Berpikir Komputasionalr 


\section{PENDAHULUAN}

Computational thinking didefinisikan oleh Jeanette Wing (mantan Wakil Presiden Microsoft Research) sebagai kompetensi seseorang dalam menganalisis suatu permasalahan dan menyajikan solusi dari permasalahan tersebut dalam sebuah algoritma yang dapat dioleh komputer (Wing, 2017). Terdapat banyak turunan definisi teknis dari pernyataan tersebut. Namun banyak peneliti menyebutkan bahwa pemecahan masalah yang melibatkan computational thinking dapat dilihat dari kemampuan seseorang dalam (1) menguraikan masalah rumit menjadi masalah-masalah yang lebih sederhana (decomposition), (2) mengenali pola-pola yang muncul dari masalah yang telah diuraikan (recognise the patterns), (3) melakukan abstraksi untuk menemukan konsep general yang dapat dipakai menyelesaikan masalah yang dihadapi (abstraction), dan (4) mengembangkan solusi dari masalah yang dihadapi (algorithm) (Bocconi et al, 2016). Banyak negara bahkan sudah secara resmi memasukkan computational thinking dalam kurikulum. Inggris adalah satu pionir negara yang secara berani memasukkan computational thinking dalam kurikulum sejak 2012.

Negara - negara maju di Asia juga mulai mengambil langkah untuk mengenalkan computational thinking dengan pendekatan yang berbeda-beda. Jepang dan Hong Kong, China, dan Taiwan memasukkan materi-materi pemrograman komputer dalam kurikulum pendidikan dasar (So, Jong, \& Liu, 2020). Sementara itu, Singapura yang mencetuskan berpikir komputasional sebagai "national capability" sebagai bagian dari kampanye transformasi Singapura menjadi "Smart Nation" (Seow, et.al, 2019). Negara jiran Malaysia juga telah melakukan integrasi berpikir komputasional dalam pendidikan mulai 2017 (Ling, et al, 2018).

Pemerintah perlu mempertimbangkan integrasi computational thinking dalam mata pelajaran wajib. Riset sebelumnya menunjukkan bahwa computational thinking dapat diintegrasikan dalam mata pelajaran yang dikategorikan "berjarak" atau tidak memiliki hubungan langsung dengan ilmu komputer. Sebuah riset di Austria, misalnya, menghasilkan temuan bahwa prinsip Unified Modeling Language (UML), yang dipelajari dalam bidang software engineering, ternyata dapat diintegrasikan dalam pembelajaran bahasa di tingkat sekolah dasar (Sabitzer, et al, 2018).

Programme for International Student Assesment (PISA) 2021 memasukkan aspek computational thinking dalam pengukuran kemampuan dalam bidang matematika (OECD, 2018). Asesmen PISA terakhir, Indonesia memperoleh hasil yang tidak menggembirakan. Indonesia meraih skor berturut-turut 371, 379, dan 396 dalam membaca, matematika, dan sains, yang tentu saja masih jauh dari rata-rata perolehan seluruh negara peserta.

Berdasarkan hasil observasi kemampuan computational thinking sebenarnya sudah diterapkan di SDN 2 Sekarteja, namun guru beserta siswa tidak sadar secara tidak langsung saat guru memberikan soal matematika berupa soal cerita dari soal tersebut sudah tergambarkan bahwa saat siswa menyelesaikan soal tersebut mereka menggunakan kemampuan analisis beserta logika, kemampuan analisis beserta logika sudah menggambarkan salah satu indikator dari kemampuan computational thinking yaitu Algoritma dan dekomposisi. 
Dari uraian yang telah dipaparkan di atas, diperlukan adanya korelasi antara kemampuan matematikan dan kemampuan computational thinking. Pada penelitian ini dilakukan pengukuran kemampuan computaional thinking ditinjau dari kemampuan matematika di SDN 2 Sekarteja. Beberapa tahun belakangan ini, CT menjadi hal yang sering dibicarakan dan sangat penting di keilmuan digital (Barr \& Stephenson, 2011). Pada tahun 1980 untuk pertama kalinya CT diterapkan dan diteliti dalam dunia pendidikan oleh Papert. Pada tahun 2006, Jeanette Wing mengenalkan CT dalam K-12. CT didefinisikan sebagai skill dasar berfikir untuk siswa dan guru dalam menyelesaikan masalah dan mengembangkan peluang.

Computational thinking terdiri dari 4 key techniques menurut Inggriani Liem (Marieska, et al., 2019), yaitu sebagai berikut : (1) Decomposition : memecahkan permasalahan yang rumit menjadi bagian-bagian yang lebih sederhana dan mudah dikerjakan, (2) Pattern Recognition : mencari kemiripan antar berbagai permasalahan, (3) Abstraction : berfokus pada informasi yang penting saja dan mengabaikan informasi yang dianggap tidak relevan, (4) Algorithms : merancang langkah-langkah untuk menyelesaikan permasalahan. Berdasarkan penjelasan tersebut dapat disimpulkan bahwa CT bertujuan untuk menyelesaikan masalah dalam berbagai bidang. Keempat indikator dapat kita konversi dalam domain Taksonomi Bloom berada pada domain paling rendah pada tingkat analisis (C4). National Council of Teacher of Mathematics (NCTM) pada tahun 1999 mendefinisikan kemampuan matematika sebagai pengetahuan dan keterampilan dalam mengeksplorasi, memprediksi dan berpikir secara logis untuk memecahkan masalah, menghubungkan gagasan antara matematika dan aktivitas intelektual lainnya. Berdasarkan penjelasan tersebut dapat disimpulkan bahwa pada awal memasuki jenjang pendidikan SD/MI siswa memulai menyerap mata pelajaran dari kelas I hingga dengan kelas VI. Alokasi waktu pembelajaran untuk SD/MI persatu jam pembelajaran adalah 35 menit, sedangkan alokasi waktu pembelajaran perminggu untuk kelas rendah antara 29 - 32 jam permbelajaran, dan untuk kelas tinggi 34 jam pelajaran perminggu (Moh \& Teguh, 2012).

Rumusan masalah pada penelitian ini adalah apakah terdapat korelasi antara kemampuan computational think dengan kemampuan matematika peserta didik. Dengan hipotesis $\left(\mathrm{H}_{1}\right)$ terdapat pengaruh antara kemampuan computational thinking terhadap kemampuan matematik peserta didik.

\section{METODE PENELITIAN}

Jenis penelitian ini adalah penelitian kuantitatif dengan metode Deskriptif. Metode deskriptif merupakan metode penelitian yang digunakan untuk mendeskripsikan dan menjawab berbagai macam persoalan dari berbagaimacam peristiwa dan fenomena yang terjadi di sekitar dalam berbagai hubungan variabel (Arifin, 2014).

Dalam penelitian ini dibentuk 1 kelompok yang terdiri dari 30 responden. Masingmasing responden diberikan tes computational thinking (Y) dan tes matematika (X) dengan pokok bahasan jarak dan kecepatan. Penelitian ini dilaksanakan di SDN 2 Sekarteja, populasi penelitian ini adalah seluruh siswa kelas 5 SDN 2 Sekarteja tahun ajaran 2019/2020 dengan jumlah total siswa adalah 30 siswa dimana seluruh siswa 
digunakan sebagai sampel dalam penelitian ini, shingga jenis sampel yang digunakan adalah sampel jenuh

\section{HASIL DAN PEMBAHASAN}

Data yang diperoleh dari penyebaran soal evaluasi kemampuan matematika dan kemampuan computational thinking diolah menggunakan aplikasi SPSS statistics 20 untuk melihat uji prasyarat yang dilakukan yakni uji normalitas dan uji linearitas dari kedua variabel yaitu kemampuan matematika ( $\mathrm{x}$ ) dan kemampuan computational thinking (y). Hasil pengujian uji normalitas menggunakan uji kolmogorov - smirnov dapat dilihat pada gambar berikut:

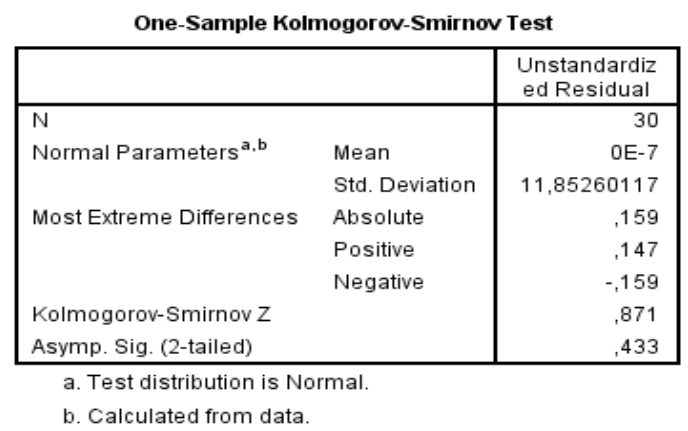

\section{Gambar 1 Hasil Uji normalitas menggunakan one sample kolmogorov-smirnov}

Dari gambar Gambar 1 Hasil Uji normalitas menggunakan one sample kolmogorov-smirnovdi atas dapat dilihat bahwa nilai signifikansi asyimp. Sig. (2-tailed) sebesar $0.433>0.05$ menunjukkan bahwa data berdistribusi normal. Dengan demikian bahwa anggapan atau prasyarat uji normalitas menggunakan model regresi dinyatakan terpenuhi. Selanjutnya dilakukan uji linearitas untuk mengetahui apakah kemampuan matematika memiliki hubungan linear yang signifikan atau tidak terhadap kemampuan computational thiking. Hasil uji linearitas dapat dilihat pada gambar berikut:

\begin{tabular}{|c|c|c|c|c|c|c|c|}
\hline \multicolumn{8}{|c|}{ ANOVA Table } \\
\hline & & & $\begin{array}{c}\text { Sum of } \\
\text { Squares }\end{array}$ & df & Mean Square & $\mathrm{F}$ & Sig. \\
\hline \multirow{5}{*}{$\begin{array}{l}\text { Kemampuan berpikir } \\
\text { komputasional anak usia } \\
\text { SD * Kemampuan } \\
\text { Matematika Siswa Usia } \\
\text { SD }\end{array}$} & Between Groups & (Combined) & 946,786 & 7 & 135,255 & .951 & .489 \\
\hline & & Linearity &, 126 & 1 &, 126 & .001 &, 977 \\
\hline & & Deviation from Linearity & 946,660 & 6 & 157,777 & 1,110 & ,388 \\
\hline & Within Groups & & 3127,381 & 22 & 142,154 & & \\
\hline & Total & & 4074,167 & 29 & & & \\
\hline
\end{tabular}

\section{Gambar 2 hasil uji linearitas kemampuan matematika terhadap kemampuan computational thinking}

Gambar 2 menunjukkan bahwa nilai deviation from linearity sig adalah $0.388>$ 0.05 yang berarti bahwa terdapat hubungan linear secara signifikan antara kemampuan matematika dan kemampuan computational thinking anak usia sekolah dasar di SD Negeri 2 Sekarteja.

Selanjutnya dilakukan uji korelasi pearson untuk melihat keeratan hubungan antara kemampuan matematika dan kemampuan computational thinking anak usia 
sekolah dasar menggunakan SPSS 20, hasil uji korelasi pearson dapat dilihat pada gambar 3 berikut:

\begin{tabular}{|ll|r|r|}
\multicolumn{1}{|c|}{ Correlations } \\
\hline & & $\begin{array}{c}\text { Kemampuan } \\
\text { berpikir } \\
\text { komputasion } \\
\text { al anak usia } \\
\text { SD }\end{array}$ & $\begin{array}{c}\text { Kemampuan } \\
\text { Matematika } \\
\text { Siswa Usia } \\
\text { SD }\end{array}$ \\
\hline Kemampuan berpikir & Pearson Correlation & 1 &, 006 \\
komputasional anak usia & Sig. (2-tailed) & 30 &, 977 \\
SD & N &, 006 & 30 \\
\hline Kemampuan Matematika & Pearson Correlation &, 977 & 1 \\
Siswa Usia SD & Sig. (2-tailed) & 30 & 30 \\
\hline
\end{tabular}

\section{Gambar 3 hasil uji korelasi pearson antara kemampuan matematika dan kemampuan computational thinking}

Berdasarkan gambar 3 tersebut dapat dilihat bahwa sig (2-tailed) sebesar $0.977>$ 0.05 menunjukkan bahwa tidak ada keearatan hubungan yang signifikan antara kemampuan matematika dan kemampuan computational thinking pada anak usia sekolah dasar di SDN 2 Sekarteja.

Berdasarkan data yang telah diperoleh dari indikator untuk mengukur kemampuan matematika, hasil tes menunjukkan kemampuan matematika pada pembelajaran matematika pokok bahasan jarak dan kecepatan sebesar 79,2\% tergolong dalam kategori "kuat". dapat dilihat pada hasil rata-rata berdasarkan indicator yang dikategorikan pada ranah domain Taxonomy Bloom, indikator pertama berada pada tingkat pengetahuan (C1) sebesar 82,0\% dalam kategori sangat kuat, indikator kedua berada pada tingkat pemahaman (C2) sebesar 75,8\% dalam kategori kuat, 77,9\% indikator ketiga pada tingkat penerapan (C3) dalam kategori sangat kuat.

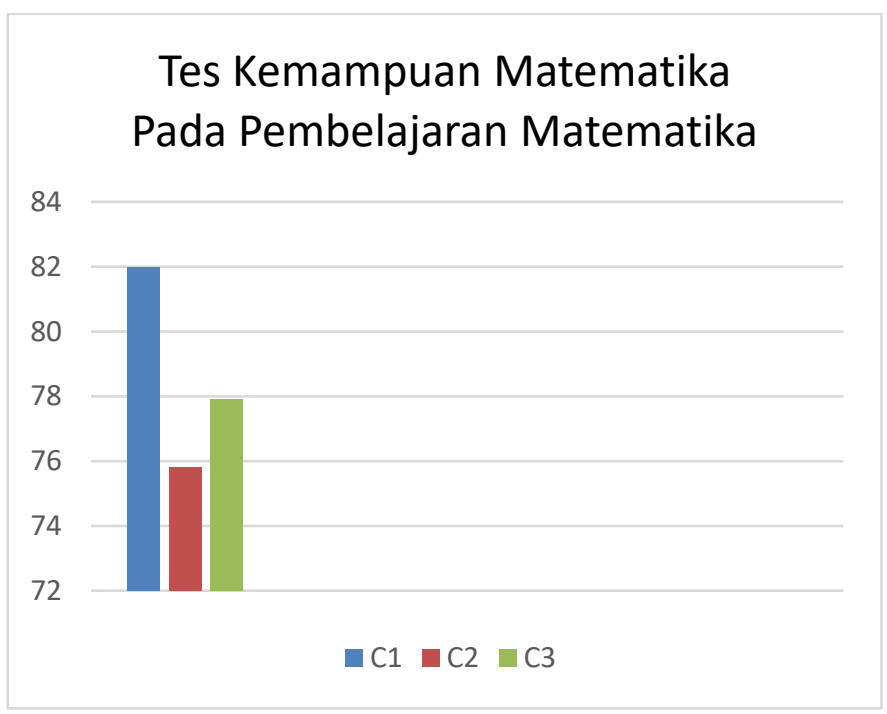

Gambar 4. Hasil Tes Kemampuan Matematika Pada Pembelajaran Matematika 
Hasil tes siswa terhadap kemampuan computational thinking menggunakan bebras task sebesar 53,16\% tergolong dalam kategori "cukup". dapat dilihat pada hasil rata-rata perindikator, indikator pertama yakni dekomposisi sebesar 68,0\% dalam kategori kuat, indikator kedua yakni pengenalan pola sebesar 55\% dalam kategori cukup, indikator ketiga yakni abstraksi sebesar 50\% dalam kategori cukup dan indikator keempat yakni algoritma sebesar 41,8\% dalam kategori cukup.

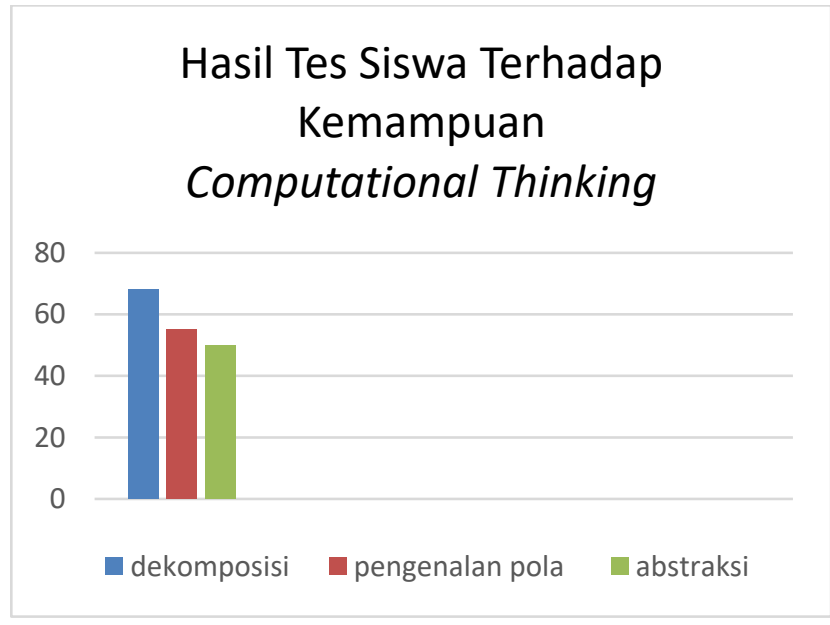

\section{Gambar 5. Hasil Tes Siswa Terhadap Kemampuan Computational Thinking}

\section{Pembahasan}

Data yang diperoleh menunjukkan bahwa antara kemampuan matematika dan kemampuan computational thinking memiliki hubungan linear yang signifikan, namun pada tingkat usia sekolah dasar keeratan hubungan kedua variabel tersebut tidak signifikan. Hasil uji korelasi pearson menunjukkan bahwa meskipun kemampuan matematika anak usia sekolah dasar tersebut berada pada kategori kuat namun tidak berpengaruh signifikan pada kemampuan computational thinking siswa.

Pengkajian lebih jauh pada indikator setiap variabel tidaklah sama, pada ranah domain taxonomy bloom kemampuan matematika anak usia sekolah dasar di SDN 2 Sekarteja paling tinggi berada pada ranah penerapan (C3), sedangkan kemampuan computational thinking membutuhkan kemampuan matematika paling rendah pada tingkat analisis (C4).

\section{SIMPULAN}

Secara umum kemampuan matematika dan kemampuan computational thinking memiliki hubungan yang searah, namun keeratan hubungan kedua variabel tersebut tidak signifikan. Faktor yang paling berpengaruh pada kemampuan computational thinking bukan hanya dilihat dari kemampuan matematika, namun ada faktor lain seperti kemampuan berpikir kritis, kemampuan pemecahan masalah, dan kemampuan literasi lainnya. Sebagai saran bahwa kemampuan computational thinking perlu diperkenalkan 
sejak usia sekolah dasar untuk menghadapi perkembangan teknologi informasi pada era revolusi industri 4.0 .

\section{UCAPAN TERIMA KASIH}

Penelitian dengan judul "Pengaruh Kemampuan Matematika Terhadap Kemampuan Computational Thinking Pada Anak Usia Sekolah Dasar” bantuan dan support yang telah diberikan banyak pihak diucapkan terima kasih. Khususnya kepada program studi Pendidikan informatika, universitas hamzanwadi dan terkhusus SDN 2 Sekarteja.

\section{DAFTAR PUSTAKA}

Arifin, Z. (2014). Penelitian Pendidikan Metode dan Paradigma Baru (A. Kamsyach (ed.)). PT Remaja Rosdakarya.

Barr, B. V.\& Stephenson, C. (2011). Call It Problem Solving, Not Computational Thinking. ACM Inroads, 2(1), 48-54.

Bocconi, S., Chioccariello, A., Dettori, G., Ferrari, A., Engelhardt, K., Kampylis, P., \& Punie, Y. (2016). Developing Computational Thinking in Compulsory Education - Implications for policy and practice. In Joint Research Centre (JRC) (Issue June).

Hendriana, H. (2014). Membangun Kepercayaan Diri Siswa Melalui Pembelajaran Matematika Humanis. Jurnal Pengajaran Matematika Dan Ilmu Pengetahuan Alam, 19(1), 52.

Ling, U. L., Saibin, T. C., Naharu, N., Labadin, J., \& Aziz, N. A. (2018). An evaluation tool to measure computational thinking skills: pilot investigation. National Academy of Managerial Staff of Culture and Arts Herald, 1, 606-614

Maharani, S., Kholid, M. N., Nico Pradana, L., \& Nusantara, T. (2019). Problem Solving in the Context of. 8(2), 109-116.

Moh, P., \& Teguh, A. P. (2012). Strategi Pengelolaan SD/MI. UIN Maliki Press.

Nuriadin, I., \& Perbowo, K. S. (2013). Analisis Korelasi Kemampuan Berpikir Kreatif Matematik Terhadap Hasil Belajar Matematika Peserta Didik Smp Negeri 3 Lurangung Kuningan Jawa Barat. Infinity Journal, 2(1), 65.

OECD. (2018). PISA 2021 mathematics framework (second draft)

Sabitzer, B., Demarle-Meusel, H., \& Jarnig, M. (2018). Computational thinking through modeling in language lessons. IEEE Global Engineering Education Conference, EDUCON, 2018-April(2), 1913-1919.

Seow, P., Looi, C.-K., How, M.-L., Wadhwa, B., \& Wu, L.-K. (2019). Educational Policy and Implementation of Computational Thinking and Programming: Case Study of Singapore. In S.-C. Kong \& H. Abelson (Eds.), Computational Thinking Education (pp. 345-361). Singapore: Springer Singapore.

So, H.-J., Jong, M. S.-Y., \& Liu, C.-C. (2020). Computational Thinking Education in the Asian Pacific Region. The Asia-Pacific Education Researcher, 29(1), 1-8.

Zahid, M. Z. (2020). Telaah kerangka kerja PISA 2021 : Era Integrasi Computational Thinking dalam Bidang Matematika. Prosiding Seminar Nasional Matematika, 3(2020), 706-713.

Wing, J. M. (2017). Computational thinking's influence on research and education for all. Italian Journal of Educational Technology, 25(2), 7-14. 